\title{
The Effects of Chloride Anions on Corrosion and Passivation Behavior of 254SMO Stainless Steel in Water Absorbed of Blast Furnace Gas (BFG)
}

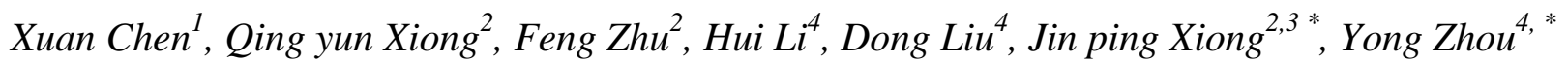 \\ ${ }^{1}$ College of Mechanical and Electrical Engineering, Beijing University of Chemical Technology, \\ Beijing 100029, China \\ ${ }^{2}$ College of Materials Science and Engineering, Beijing University of Chemical Technology, Beijing \\ 100029, China \\ ${ }^{3}$ Beijing Key Laboratory of Electrochemical Process and Technology for Materials, Beijing University \\ of Chemical Technology, Beijing 100029, China \\ ${ }^{4}$ Key Laboratory for Green Chemical Process of Ministry of Education, Wuhan Institute of \\ Technology, Wuhan 430205, China \\ *E-mail: xiongjp@ mail.buct.edu.cn, zhouyong@ wit.edu.cn
}

doi $10.20964 / 2018.02 .28$

Received: 24 October 2017 / Accepted: 5 December 2017 / Published: 28 December 2017

The effects of chloride anions $\left(\mathrm{Cl}^{-}\right)$on the corrosion and passivation behavior of 254SMO stainless steel in an electrolyte that was obtained by water absorption of blast furnace gas (BFG) were studied by the electrochemical measurements of potentiodynamic polarization, electrochemical impedance spectroscopy (EIS), potential step and Mott-Schottky plot. The 254SMO steel showed the electrochemical characteristic of spontaneous passivation in the studied electrolyte with different concentrations of $\mathrm{Cl}^{-}$, and the effects of $\mathrm{Cl}^{-}$concentration on the values of passivation current density $\left(i_{\text {pass }}\right)$, pitting potential $\left(E_{\text {pit }}\right)$, repassivation potential $\left(E_{\text {rep }}\right)$, passive film resistance $\left(R_{f}\right)$, passive film capacitance $\left(C E P_{f}\right)$, donor density $\left(N_{D}\right)$ and flat bond potential $\left(U_{f b}\right)$ presented a certain law but was not very prominent. Further, in the studied $\mathrm{Cl}^{-}$concentration range from $20 \mathrm{~g} / \mathrm{L}$ to $120 \mathrm{~g} / \mathrm{L}$, the 254SMO steel showed good passivation capability in the studied electrolyte, and the passivation capability for the surface of 254SMO stainless steel at the low $\mathrm{Cl}^{-}$concentration was greater than that at the high $\mathrm{Cl}^{-}$concentration.

Keywords: 254SMO stainless steel; blast furnace gas (BFG); corrosion; passivation; chloride anion $\underline{\text { FULL TEXT }}$ 
(C) 2018 The Authors. Published by ESG (www.electrochemsci.org). This article is an open access article distributed under the terms and conditions of the Creative Commons Attribution license (http://creativecommons.org/licenses/by/4.0/). 